\title{
Surface micropatterning with zirconia and calcium phosphate ceramics by micromoulding in capillaries
}

Citation for published version (APA):

Baiao Barata, D., Resmini, A., Pereira, D., Veldhuis, S. A., van Blitterswijk, C. A., ten Elshof, J. E., \& Habibovic, P. (2016). Surface micropatterning with zirconia and calcium phosphate ceramics by micromoulding in capillaries. Journal of Materials Chemistry. B, Materials for Biology and Medicine, 4(6), 1044-1055. https://doi.org/10.1039/c5tb02027a

Document status and date:

Published: 01/01/2016

DOI:

10.1039/c5tb02027a

Document Version:

Publisher's PDF, also known as Version of record

Document license:

Taverne

Please check the document version of this publication:

- A submitted manuscript is the version of the article upon submission and before peer-review. There can be important differences between the submitted version and the official published version of record.

People interested in the research are advised to contact the author for the final version of the publication, or visit the DOI to the publisher's website.

- The final author version and the galley proof are versions of the publication after peer review.

- The final published version features the final layout of the paper including the volume, issue and page numbers.

Link to publication

\footnotetext{
General rights rights.

- You may freely distribute the URL identifying the publication in the public portal. please follow below link for the End User Agreement:

www.umlib.nl/taverne-license

Take down policy

If you believe that this document breaches copyright please contact us at:

repository@maastrichtuniversity.nl

providing details and we will investigate your claim.
}

Copyright and moral rights for the publications made accessible in the public portal are retained by the authors and/or other copyright owners and it is a condition of accessing publications that users recognise and abide by the legal requirements associated with these

- Users may download and print one copy of any publication from the public portal for the purpose of private study or research.

- You may not further distribute the material or use it for any profit-making activity or commercial gain

If the publication is distributed under the terms of Article $25 \mathrm{fa}$ of the Dutch Copyright Act, indicated by the "Taverne" license above, 


\section{Journal of} Materials Chemistry B Materials for biology and medicine www.rsc.org/MaterialsB
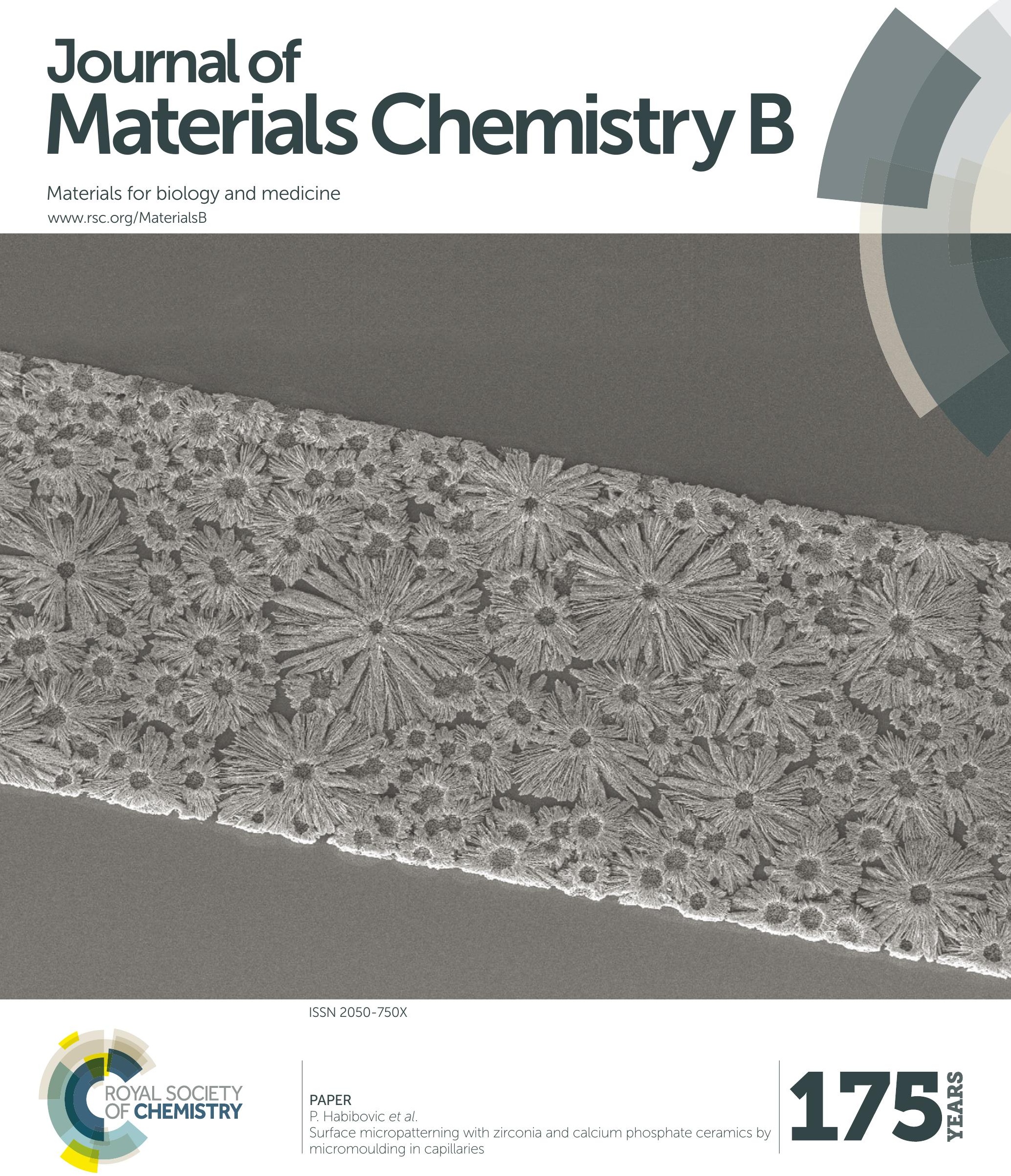

\section{PAPER}

P. Habibovic et al.

Surface micropatterning with zirconia and calcium phosphate ceramics by micromoulding in capillaries

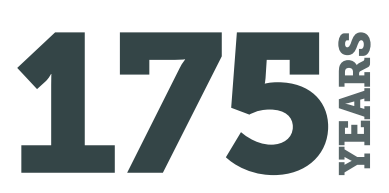


CrossMark \& click for updates

Cite this: J. Mater. Chem. B, 2016, 4, 1044

\title{
Surface micropatterning with zirconia and calcium phosphate ceramics by micromoulding in capillaries
}

\author{
D. Barata, ${ }^{a}$ A. Resmini, ${ }^{\text {b }}$ D. Pereira, ${ }^{\text {ac }}$ S. A. Veldhuis, ${ }^{\text {b }}$ C. A. van Blitterswijk, ${ }^{\text {ac }}$ \\ J. E. ten Elshof ${ }^{b}$ and P. Habibovic*ac
}

\begin{abstract}
An increasing demand exists for biomaterials that are able to actively participate in the process of repair and regeneration of damaged or diseased organs and tissues. Patterning of surfaces of biomaterials with distinct chemical or physical cues is an attractive way to obtain spatial control over their interactions with the biological system. In the current study, micromoulding in capillaries method was used to pattern silicon substrates with bioinert yttria-stabilised zirconia or with bioactive calcium phosphate ceramics, both widely used biomaterials in orthopaedics and dentistry. Micrometer-scale patterns consisted of parallel lines with varying width and spacing. Both ceramics were successfully deposited on the substrate in a pattern defined by the mould. While the yttria-stabilised zirconia pattern was highly homogenous and smooth $\left(R_{\mathrm{q}}=5.5 \mathrm{~nm}\right)$, the calcium phosphate pattern, consisting of dicalcium phosphate anhydrous before, and of $\beta$-tricalcium phosphate after annealing, exhibited a less homogenous morphology and higher roughness $\left(R_{\mathrm{q}}=893 \mathrm{~nm}\right)$. Both materials allowed attachment and proliferation of the MG-63 osteosarcoma cell line, independent of the pattern used. While a preferential orientation of cells in the direction of the pattern lines was observed for all patterns, this effect was more pronounced on the lines with a width of up to $20 \mu \mathrm{m}$ on both yttriastabilised zirconia and calcium phosphate ceramics, as compared to wider patterns. Furthermore, the cells retained an elongated morphology for a longer period of time on narrow patterns. Micromoulding in capillaries appeared to be a suitable method to pattern both types of ceramics, however further optimisation is needed to improve homogeneity and obtain better control over the chemical phase and crystalline structure of calcium phosphate patterns.
\end{abstract}

Received 29th September 2015 Accepted 13th December 2015

DOI: $10.1039 / c 5 t b 02027 a$

www.rsc.org/MaterialsB

\section{Introduction}

Design of biomaterials for regenerative medicine is progressing towards greater control over the biological response in vivo. This is a logical consequence of the changing role of biomaterials, from being bioinert and passively taking over a role of the damaged tissue in the long term, to being bioactive and actively participating in the process of regeneration and recovery of normal function. ${ }^{1,2}$ A biomaterial is expected, on the one hand, to support cell attachment, growth and even differentiation towards the desired lineage, and on the other hand, to facilitate the management of the inflammatory response, while providing

\footnotetext{
${ }^{a}$ Department of Tissue Regeneration, MIRA Institute for Biomedical Technology and Technical Medicine, University of Twente, P. O. Box 217, 7500 AE Enschede, The Netherlands

${ }^{b}$ MESA+ Institute for Nanotechnology, Inorganic Materials Science Group, University of Twente, P.O. Box 217, 7500 AE Enschede, The Netherlands ${ }^{c}$ MERLN Institute for Technology-Inspired Regenerative Medicine, Maastricht University, P.O. Box 616, 6200 MD Maastricht, The Netherlands. E-mail: p.habibovic@maastrichtuniversity.nl
}

the necessary mechanical support on a time scale suitable for repair or regeneration of the tissue. ${ }^{3}$ This kind of instructed regeneration requires an adequate level of knowledge about the interactions between biomaterials and the biological system. The focus is thereby on the interface between the material and the surrounding physiological environment, where surface properties play an important role. ${ }^{4}$ Far from being just a boundary, the cell-material interface constitutes the origin of new tissue formation, as it provides support for the host cells to adhere and proliferate.

Patterning of the biomaterial surface with distinct chemical or physical cues is an attractive way to obtain spatial control over its interactions with the biological system. Recently, Yao et al. reviewed a number of techniques to fabricate patterns at microand nanoscales and the applicability of such platforms to screen cell-material interactions. ${ }^{5}$ An example includes patterning of Arg-Gly-Asp peptides on a (poly)ethyleneglycol hydrogel, which enabled to investigate effects of the cell area, ${ }^{6}$ aspect ratio ${ }^{7}$ or subcellular edge curvature ${ }^{8}$ on the differentiation of various cell types. Micropatterning of surfaces with natural or synthetic 
molecules has also been used to control regenerative processes, such as, for example, guidance of axons growth, relevant in neuronal regeneration. ${ }^{9}$ The large majority of current patterning techniques involves polymers or biomolecules, which is not surprising, considering their relative ease of handling. Patterning of ceramic materials, which are intrinsically hard and brittle, has been explored to a much lesser extent. This is despite the widespread clinical use of various types of ceramics. For example, yttria-stabilised zirconia (YSZ) is widely used in the field of dentistry, due to improved aesthetics and higher corrosion resistance as compared to most metals and a better crack formation resistance than alternative ceramics. ${ }^{10,11}$ Bioactive ceramics, such as calcium phosphates (CaP), are extensively used in regenerative medicine, with emphasis on hard tissue regeneration. $^{12-14}$

The currently available techniques for patterning of ceramic materials suffer from a number of important limitations. For example, micromachining and laser ablation possess poor accuracy below the $100 \mu \mathrm{m}$ size threshold. ${ }^{15}$ Higher-resolution techniques such as focused ion beam, electron beam writing and nano-imprint lithography are time-consuming, low-throughput processes that require expensive equipment; physical and chemical deposition, being thermodynamically driven processes, do not allow patterning of ordered structures and are applicable only to a limited range of materials. ${ }^{16,17}$

A promising way to overcome the difficulties associated with patterning of ceramic materials comes from the family of soft lithography methods, which were developed in the 1990s inspired by the process of photolithography for microelectronics, and applied to studies of cell behaviour. ${ }^{18}$ Soft lithographic methods such as micromoulding in capillaries (MIMIC), ${ }^{19}$ microtransfer moulding $(\mu \mathrm{TM}),{ }^{20}$ micromoulding ${ }^{21}$ and microcontact printing $(\mu \mathrm{CP})^{22}$ employ an elastomeric stamp or mould together with a liquid precursor. They offer the advantages of low cost fabrication and technical simplicity, while remaining highly accurate when compared to more traditional processes such as micromachining or laser ablation. Moreover, soft lithography methods allow for patterning of thin films instead of bulk ceramics, which is a major advantage for patterning applications as it allows deposition of ceramic phases against a different background. ${ }^{15}$

A variety of inorganic materials have been patterned using a combination of MIMIC and sol-gel chemistry, including functional oxide ceramics such as $\mathrm{SnO}_{2}$ and $\mathrm{ZrO}_{2}{ }^{23} \mathrm{ZnO},{ }^{24} \mathrm{TiO}_{2}{ }^{25}$ YSZ, ${ }^{26}$ piezoelectric PZT and strontium niobate $\left(\mathrm{Sr}_{2} \mathrm{Nb}_{2} \mathrm{O}_{7}\right),{ }^{27}$ and several luminescent materials ${ }^{28-33}$ or non-oxide ceramics such as $\mathrm{SiC}^{34}$ and SiCN. ${ }^{35}$ Few examples exist of studies in which bioactive ceramics were patterned on chemically different substrates. Recently, a combination of micromoulding and solgel chemistry was used to micropattern $\mathrm{SiO}_{2}$ on a zirconia substrate, which could be used to enhance the metabolic activity of fibroblasts and endothelial cells, while reducing bacterial adhesion. $^{36,37}$ In another example, a photolithography-based method was used to deliver patterns of hydroxyapatite on a polyethylene glycol (PEG) passivated glass substrate, resulting in localization of MC3T3 osteoblasts exclusively on the bioceramic patterns. ${ }^{38}$ These few available examples show the potential of patterning bioactive ceramics to spatially control biological processes in the fields where such materials are widely applied, such as orthopaedics and dentistry. The number of clinical challenges that could be addressed by patterning bioactive ceramics is high. For example, patterns of bioactive ceramics such as CaPs could be used for improving the integration of (metallic) orthopaedic or dental implants into the surrounding tissue, for controlling regenerative potential of synthetic bone graft substitutes or for improving the soft to hard tissue interaction, in, for example, tendon or ligament replacement surgeries. Based on these clinical challenges, rendering the available ceramic patterning techniques suitable for patterning more bioactive ceramics remains a topic of interest.

Here, we describe the patterning of two types of ceramics, i.e. YSZ and CaPs on a silicon substrate through a soft lithography approach. YSZ, an inert ceramic used e.g. in dental implants, ${ }^{39}$ was obtained by the sol-gel method as described previously. ${ }^{26}$ A bioactive CaP ceramic, deposited in the form of dicalcium phosphate anhydrous (DCPA), and transformed into $\beta$-tricalcium phosphate ( $\beta$-TCP) after heat-treatment, was deposited by precipitation from a saturated CaP solution. Upon detailed characterization, MG-63 human osteosarcoma cells were seeded on both bioinert and bioactive ceramic patterns and their morphology, metabolic activity and proliferation were assessed qualitatively and quantitatively.

\section{Experimental}

Zirconium(Iv) $n$-propoxide $\left(\mathrm{Zr}\left[\left(\mathrm{OC}_{3} \mathrm{H}_{7}\right)\right]_{4}\right), 70 \mathrm{w} / \mathrm{w} \%$ in 1-propanol and yttrium(III) nitrate hexahydrate $\left(\mathrm{Y}\left(\mathrm{NO}_{3}\right)_{3} 6 \mathrm{H}_{2} \mathrm{O}\right.$, purity $\left.99.9 \%\right)$ were purchased from Alfa Aesar. Glacial acetic acid (HAc, 99.8\%), 2-methoxyethanol (99.3\%), 1-propanol (99.9\%), and ethylene glycol (99.8\%) were acquired from Sigma-Aldrich. All chemicals were used as received from the suppliers. Due to the high reactivity of zirconium(Iv) $n$-propoxide, the solution was stored and handled in a water-free environment $\left(<0.1 \mathrm{ppm}_{2} \mathrm{O}\right)$.

A polydimethylsiloxane (PDMS) Sylgard 184 elastomer kit was purchased from Dow Corning, USA. Calcium nitrate $\mathrm{Ca}\left(\mathrm{NO}_{3}\right)_{2} \cdot 4 \mathrm{H}_{2} \mathrm{O}$, phosphoric acid $\mathrm{H}_{3} \mathrm{PO}_{4} 85$ wt $\%$ in $\mathrm{H}_{2} \mathrm{O}$, Triton $\mathrm{X}-100$, Tween-20, bovine serum albumin (BSA) and hexamethyldisilazane (HMDS) were obtained from Sigma-Aldrich, USA, and used without further processing. Phosphate buffered saline (PBS), Minimum Essential Medium $\alpha$ ( $\alpha$-MEM), fetal bovine serum (FBS) and trypsin were obtained from Gibco, Life Technologies, USA. Fluorescein isothiocyanate (FITC) conjugated antibody for vinculin, focal adhesion kinase (FAK) rabbit antibody, F-actin probe Alexa Fluor 594 for phalloidin, secondary antibody Alexa Fluor 647 anti-rabbit and 4',6-diamidino-2-phenylindole (DAPI) were purchased from Invitrogen, Life Technologies, USA. Presto Blue $^{\mathrm{TM}}$ cell viability assay and CyQUANT ${ }^{\mathrm{TM}}$ cell proliferation assay were from Invitrogen, Life Technologies, USA. CDPstar 0.25 ready-to-use solution for ALP quantification was from Roche, Switzerland. Human osteosarcoma cell line MG-63 (ATCC CRL-1427) was obtained from ATCC-LGC, United Kingdom. 


\section{Preparation of moulds}

PDMS moulds were prepared by replica moulding of a silicon wafer master. The Si-master was patterned by standard photolithographic processing, followed by deep reactive ion etching (Adixen SE, Alcatel, France). PDMS was prepared by mixing the elastomer base and curing agent in a 10:1 mass ratio, and subsequent curing at $80{ }^{\circ} \mathrm{C}$ for 2 hours (Fig. 1a). The mould was peeled from the Si-master, patterns were manually cut from the replicated PDMS and carefully cleaned with nitrogen gas blow before conformal contact with a silicon piece, previously cut to match the mould size. The mould features consisted of an array of parallel grooves of $2 \mu \mathrm{m}$ depth and variable width and spacing: $5,10,20,40$, and $80 \mu \mathrm{m}$.

\section{Zirconia micropatterning}

Preparation of the precursor solution. Precursor solutions of 3 mol\% yttria-stabilized zirconia (3YSZ) were prepared according to the procedure described earlier. ${ }^{26}$ Briefly, a solution with
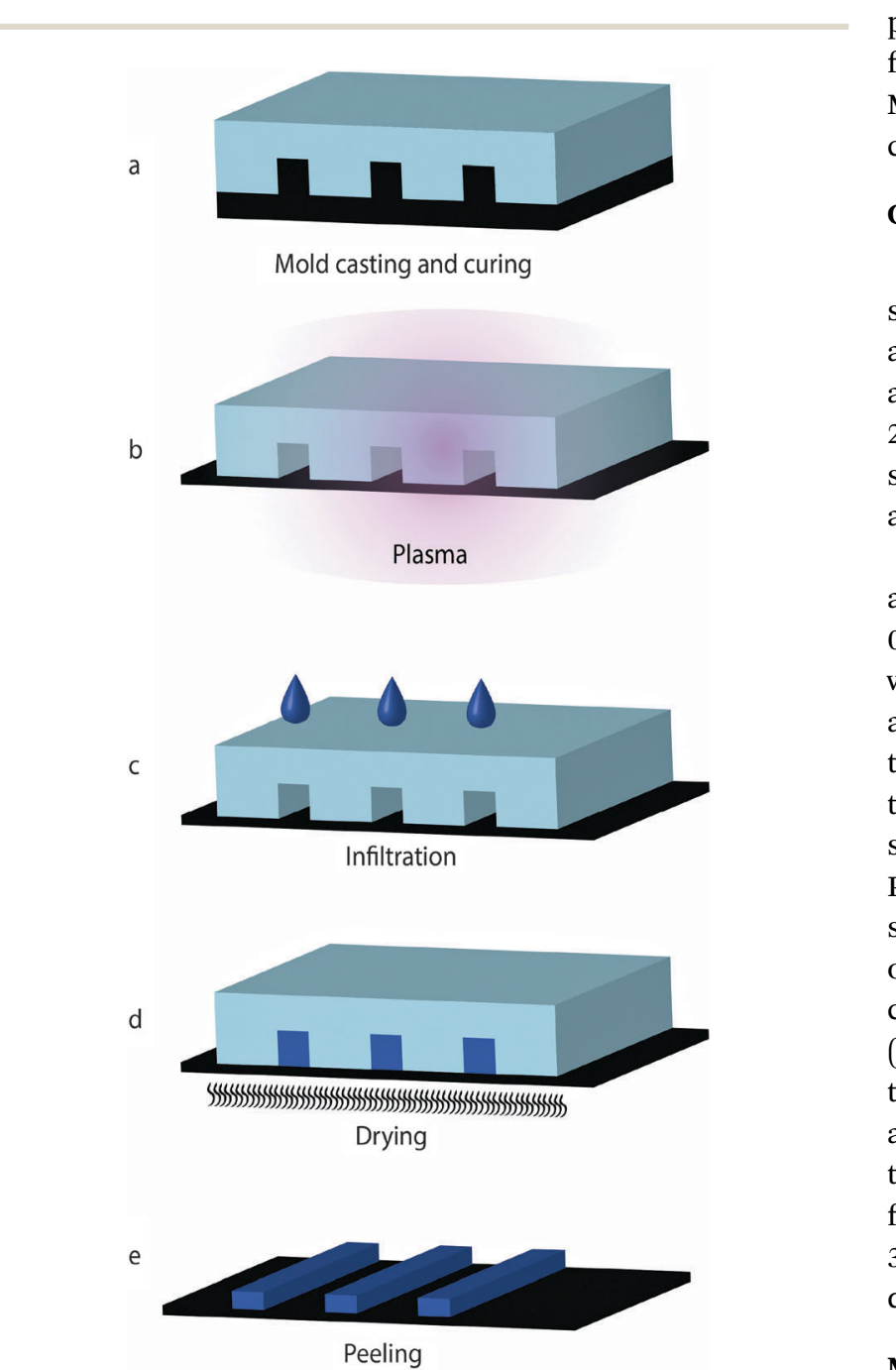

Fig. 1 Schematic of the patterning method. Casting of PDMS and curing to develop a mould (a), air plasma treatment on the mould-substrate assembly (b), infiltration of the solution in the channels (c), drying of solution (d) and removal of mould (e). a final concentration of $[\mathrm{Zr}]=0.57 \mathrm{M}$ was prepared in 2-methoxyethanol under a nitrogen atmosphere, using a molar ratio of $\mathrm{Zr} / \mathrm{HAc} / \mathrm{H}_{2} \mathrm{O}=1: 4: 5$. To promote a more rapid infiltration of the channels, $5 \%(\mathrm{v} / \mathrm{v})$ of ethylene glycol (EG) was added to the solution. After addition of EG, the solution was used immediately.

Fabrication of 3YSZ patterns. Prior to patterning, the PDMS moulds were treated in an air plasma chamber operating at $24 \mathrm{~W}$ for $150 \mathrm{~s}$ to increase the hydrophilicity of the mould (Fig. 1b). Fresh precursor solution $(\sim 50 \mu \mathrm{L})$ was added as a drop on a cleaned Si surface. A PDMS mould was placed on top, and a uniaxial force (uniformly distributed) of approximately $11 \mathrm{~N}$ was carefully applied to promote filling of the as-formed microchannels and to prevent the formation of a residual layer. A drop of freshly prepared 3YSZ sol was placed at the openings of the microchannels (Fig. 1c). The assembly was allowed to dry at room temperature under the applied pressure, and then heated for $1 \mathrm{~h}$ at $60{ }^{\circ} \mathrm{C}$ (Fig. 1d). The PDMS mould was then carefully removed, and an array of parallel lines of the amorphous ceramic was obtained (Fig. 1e). Additional heat treatment for $1 \mathrm{~h}$ at $850{ }^{\circ} \mathrm{C}$ in a microwave oven (heat/cool $20{ }^{\circ} \mathrm{C} \mathrm{min}^{-1}$; MultiFAST, Milestone, Sorisole, Italy) ensured the formation of crystalline 3 YSZ features.

\section{Calcium phosphate micropatterning}

Preparation of the precursor solution. For CaP patterns, two stock aqueous solutions were prepared: a $1.0 \mathrm{M}$ calcium nitrate and a $0.67 \mathrm{M}$ phosphoric acid solution. Each solution was stored at $4{ }^{\circ} \mathrm{C}$ in plastic bottles until further use. Prior to the patterning, $2 \mathrm{~mL}$ of each solution was filtered through a $0.2 \mu \mathrm{m}$ Nalgene ${ }^{\mathrm{TM}}$ syringe (SFCA filter) and the solutions were then mixed to obtain a final calcium to phosphate ionic ratio of 1.5 .

Fabrication of CaP patterns. Prior to patterning, the mould and substrate assembly was placed in a plasma chamber (PDC002 from Harrick Plasma, USA) and treated for $10 \mathrm{~min}$ (line width $\geq 10 \mu \mathrm{m}$ ) or $20 \mathrm{~min}$ (line width $<10 \mu \mathrm{m}$ ), in a $0.1-0.2 \mathrm{mbar}$ air atmosphere, at $7 \mathrm{~W}$ (Fig. 1b). Different plasma treatment times were applied in order to obtain the same plasma penetration into microchannels of different sizes, ${ }^{40}$ and therewith equal solution infiltration times. The microchannels formed by the PDMS mould and Si substrate were infiltrated with the CaP solution by pipetting a droplet $(\sim 10 \mu \mathrm{L})$ at both sides of the open microchannels (Fig. 1c). The solution was left in the channels overnight, before drying for $6 \mathrm{~h}$ at $60{ }^{\circ} \mathrm{C}$ on a hotplate (Fig. 1d). Subsequently, the PDMS mould was peeled off from the Si substrate, revealing the patterned CaP structures (CaP-AP; as-prepared) (Fig. 1e). The selected $\mathrm{CaP}$ patterns received additional heat treatment for $3 \mathrm{~h}$ at $950{ }^{\circ} \mathrm{C}$ (the average heating rate from RT to $950{ }^{\circ} \mathrm{C}$ was $32{ }^{\circ} \mathrm{C}$ and the average cooling rate to RT was $3.3{ }^{\circ} \mathrm{C}$ ) in air to obtain a different CaP crystalline phase (further denoted as CaP-HT; high-temperature).

\section{Material characterization}

The crystalline phase was identified by X-ray diffraction (XRD; $\mathrm{X}$ Pert ${ }^{3}$ Powder from PANalytical, Netherlands). The diffractometer used $\mathrm{Cu}-\mathrm{K} \alpha$ irradiation $(\lambda=1.5418 \AA)$, a Ni filter, and measurements 
were performed between $2 \theta=10^{\circ}$ and $68^{\circ}$, with a step size of $0.013^{\circ}$, and a total scanning time of $1000 \mathrm{~s}$ per step using a PIXcel 3D detector. The morphology of the patterned structure was analyzed by scanning electron microscopy (SEM; Philips XL-30, Netherlands), coupled with elemental analysis performed by energy-dispersive X-ray spectroscopy (EDX; TEAM ${ }^{\mathrm{TM}}$ EDS system from EDAX, USA). CaP patterns were sputter-coated with gold $(30 \mathrm{~mA}, 40 \mathrm{~s})$. Root mean square roughness $\left(R_{\mathrm{q}}\right)$ values were calculated from white light interferometry mapping (Bruker Contour GT-I).

\section{Preparation of standard samples for cell culture}

To ensure standardized cell culture surfaces, $1 \mathrm{~cm}^{2}$-sized patterned areas were cut from the larger patterned substrate. The excess deposited material usually found at the edges of the PDMS mould after the MIMIC method was thus removed from the substrates for cell culture.

Substrates for cell culture were prepared in triplicate. Unpatterned Si substrates and tissue culture plastic (TCP) were used as controls.

\section{Cell culture}

Prior to cell culture, all substrates were sterilized by washing twice with $70 \%$ ethanol for $5 \mathrm{~min}$ and once with phosphate buffered saline (PBS) solution for $5 \mathrm{~min}$. Substrates were transferred to new tissue culture treated plastic well plates, washed again with PBS for $5 \mathrm{~min}$ and incubated in cell-culture medium for at least $30 \mathrm{~min}$ before aspiration and cell seeding.

Human osteosarcoma cell line MG-63, a frequently used cell line in the research field of bone regeneration, was used with minimum essential medium $\alpha$ ( $\alpha$-MEM) supplemented with $10 \%$ fetal bovine serum (FBS), 1\% penicillin and streptomycin and 1\% L-glutamine. Cells were cultured at $37{ }^{\circ} \mathrm{C}$ in a humidified atmosphere and $5 \% \mathrm{CO}_{2}$. The culture medium was replaced every 2 to 3 days. Upon reaching $80-90 \%$ confluence, cells were trypsinized with $0.25 \%$ trypsin in ethylene-diamine-tetraacetic acid (EDTA) for 5 minutes at $37{ }^{\circ} \mathrm{C}$. Trypsin was inactivated with three times the volume of medium, and cells were sub-cultured in standard culture flasks or seeded for experiments. In all experiments, MG-63 cells were seeded at a density of 7500 cells per $\mathrm{cm}^{2}$, in a working volume of $1.5 \mathrm{~mL}$ for 24 -well plates and $2.5 \mathrm{~mL}$ for 12 -well plates.

\section{Metabolic activity and proliferation}

A Presto Blue $\mathrm{e}^{\mathrm{TM}}$ cell viability assay was used to quantitatively assess the cell metabolic activity. DNA quantification was performed with the CyQUANT ${ }^{\mathrm{TM}}$ cell proliferation assay. Cells were cultured as described above, and at each time interval - days 1, 3 and 7 the medium was removed, samples were washed once with PBS, and subsequently transferred to a new well plate. The samples were left to incubate with the Presto Blue ${ }^{\mathrm{TM}}$ reagent $(10 \%$ in medium) for 2 hours, in parallel with a control measurement (i.e. medium without cells). At the abovementioned time points, the DNA amounts were quantified, as a measure of the cell number. Cell lysates were obtained by incubating the substrates in $500 \mu \mathrm{L}$ of lysis buffer for 1 hour and further processed according to the manufacturer's instructions. A standard curve $\left(0,0.25,0.50,0.75,1.00,1.25,1.50\right.$, and $\left.2.00 \mu \mathrm{g} \mathrm{mL} L^{-1}\right)$ and control (without DNA) were prepared in parallel. Fluorescence was measured at $520 \mathrm{~nm}$ using a spectrophotometer (Victor3, Perkin-Elmer, USA).

\section{Cell attachment and morphology}

Cell attachment and morphology were evaluated on 3YSZ patterned lines with a width of 20 and $40 \mu \mathrm{m}$ (a size comparable to that of a diameter of a cell), with equal line spacing, while on CaP-HT patterned structures of parallel lines the experiment was expanded to a range of increasing line widths and spacings; 1, 2, 3, $4,5,10,20,40$, and $80 \mu \mathrm{m}$. Flat Si substrates were used as control. Cells were seeded and cultured for 1 or 3 days, as described above, in duplicate. For staining, the cells were fixated for $20 \mathrm{~min}$ with a $4 \%(\mathrm{v} / \mathrm{v})$ paraformaldehyde solution, permeabilized with $0.1 \%(\mathrm{v} / \mathrm{v})$ Triton X-100 for $5 \mathrm{~min}$, and finally blocked with $2 \%(\mathrm{v} / \mathrm{v}) \mathrm{BSA}$ in PBST for $30 \mathrm{~min}$. Fluorescein isothiocyanate (FITC) conjugated antibody for vinculin $(1: 750)$ was incubated overnight in combination with primary rabbit antibody for FAK $(1: 500)$ at $4{ }^{\circ} \mathrm{C}$. The samples were then incubated with F-actin probe Alexa Fluor ${ }^{\circledR} 594$ phalloidin $(1: 40)$ combined with secondary antibody Alexa Fluor ${ }^{\mathbb{R}}$ 647 anti-rabbit $(1: 400)$ for $1 \mathrm{~h}$, washed twice with PBS, and finally incubated with DAPI $(1: 100)$ for $10 \mathrm{~min}$ to stain the nucleus. Finally, the samples were imaged using a fluorescence microscope equipped with a mercury lamp (BD Pathway ${ }^{\mathrm{TM}} 435, \mathrm{BD}$ Biosciences, USA) at $20 \times$ magnification.

Quantitative analysis of MG-63 cell morphology, in terms of cytoskeleton organization upon attachment and proliferation, was performed using image analysis software CellProfiler. The parameters chosen to describe cell morphology were the orientation, area and form factor. Cell orientation was measured as the difference between the cell major axis and the direction of the patterned lines, in degrees, with $0^{\circ}$ indicating perfect alignment and $90^{\circ}$ indicating perpendicular orientation to the patterns. The area was given by the number of pixels occupied and the form factor was used as a descriptor for cell elongation.

SEM images (SEM; Philips XL-30, Netherlands) were also obtained for confirming cellular morphology and attachment. After fixation, the samples were washed with PBS and dehydrated in graded ethanol series - 50, 60, 70, 80, 90, 95, and 100\% (v/v) for 20 minutes each, followed by $20 \mathrm{~min}$ in HMDS. After removal of the HMDS, samples were dried overnight and subsequently Au coated by RF sputtering.

\section{Statistical analysis}

Assessment of significant differences between average values was performed by one-way analysis of variance (ANOVA) with Tukey's multiple comparison post hoc test. The level of significance was set at $p<0.05$. This notation applies to all figures: ${ }^{*} p<0.05,{ }^{* *} p<0.01$, and ${ }^{* *} p<0.001$.

\section{Results and discussion}

In the current study, first, a previously established MIMIC method $^{26}$ was used to deposit YSZ patterns on a silicon substrate. 
The method was optimized for patterning of larger surfaces that allow an in vitro study of cell-material interactions. To this end, the precursor solution was enriched with ethylene glycol, which improved wettability and solution infiltration, allowing complete filling of the capillaries. In the second part of the study, the technique was adapted to deposit patterns of $\mathrm{CaP}$ on the surface.

\section{Zirconia micropatterning}

Pattern characterization. The YSZ patterning procedure resulted in the deposition of a crystalline 3YSZ (97 mol\% $\mathrm{ZrO}_{2}-$ $3 \mathrm{~mol} \% \mathrm{Y}_{2} \mathrm{O}_{3}$ ) phase on the substrate, as was confirmed by the XRD analysis (Fig. 2A). The XRD patterns exhibited peaks at $2 \theta=30.4^{\circ}(111), 35.1^{\circ}(002)$ and $52.0^{\circ}(022)$, characteristic of 3YSZ (PDF\# 01-070-4426). ${ }^{41}$ The pattern coverage of the substrate and microstructural properties of the deposited material were analysed using SEM (Fig. 2C1). A clearly delimited linear pattern, defined by the PDMS mould used for patterning, was observed. EDS elemental mapping confirmed the presence of two geometrically defined phases on the sample, the silicon substrate (Fig. 2C2, D1) and the deposited ceramic phase consisting of yttrium (Fig. 2C3, D2) and zirconia (Fig. 2C4, D2). No polymeric residues were observed in the contact region between PDMS and the Si substrate, a problem that is usually associated with the micromoulding step. SEM analysis of the 3YSZ patterns demonstrated a flat surface, which was further confirmed by the white light interferometry mapping (Fig. 2B), showing extensive homogeneity in height profiles of the deposited material. A roughness calculation based on the height profile obtained by interferometry yielded $5.5 \pm 1.1 \mathrm{~nm}$ in the longitudinal direction (Ld), and $4.3 \pm 0.5 \mathrm{~nm}$ in the crossing direction (Cd). The two values, being of the same order of magnitude, reflect minor deflection upon the drying process at the edges. Drying profile dynamics have been previously discussed for zirconia sol-gel patterning by MIMIC, ${ }^{26,42}$ showing peak formation derived from faster drying at edges, due to the local higher surface area-to-volume ratio.

Cell proliferation, metabolic activity and morphology on 3YSZ patterns. The cell-material interface has been shown to constitute the origin of new tissue formation, providing chemical and mechanical scaffolding for host cells to adhere, organise and proliferate. ${ }^{43,44}$ For example, topographical features of the surface in contact with cells have been shown to play an important role in many biochemical pathways regulating their fate. ${ }^{45-47}$ Here, we studied the attachment and viability of the MG-63 osteosarcoma cell line, as well as their morphology resulting from the contact with the 3YSZ patterns. Exponential cell growth was observed on 3YSZ patterned samples over a 7 day period, as shown in Fig. 3A, supported by a comparable metabolic activity increase (Fig. 3B). While a temporal increase of the DNA amount was also observed on the flat silicon substrate, the metabolic activity of the cells did not change in time. These data showed that the patterned substrates allowed cell attachment and proliferation,
A

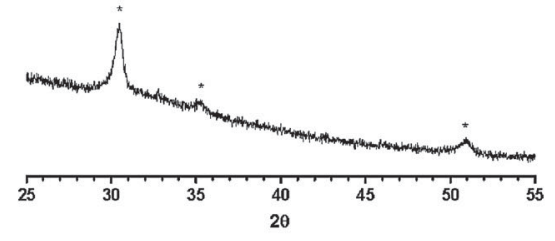

B

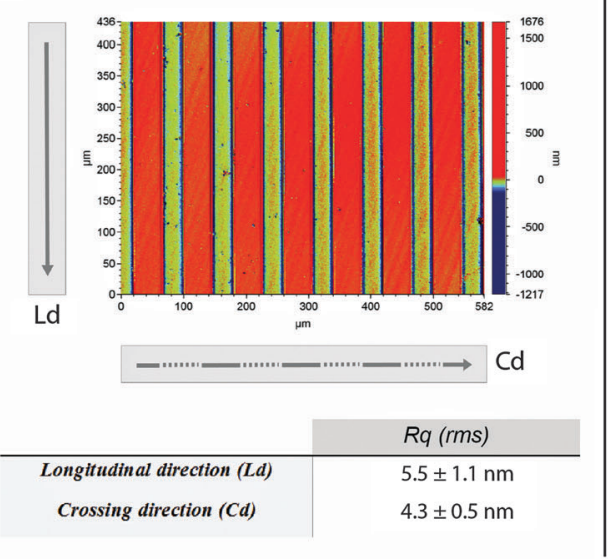

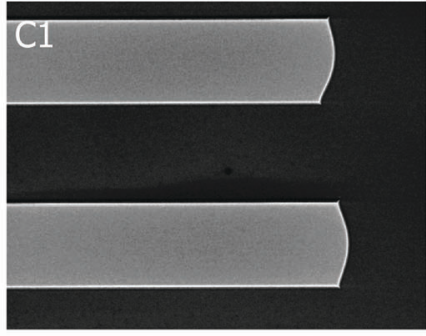
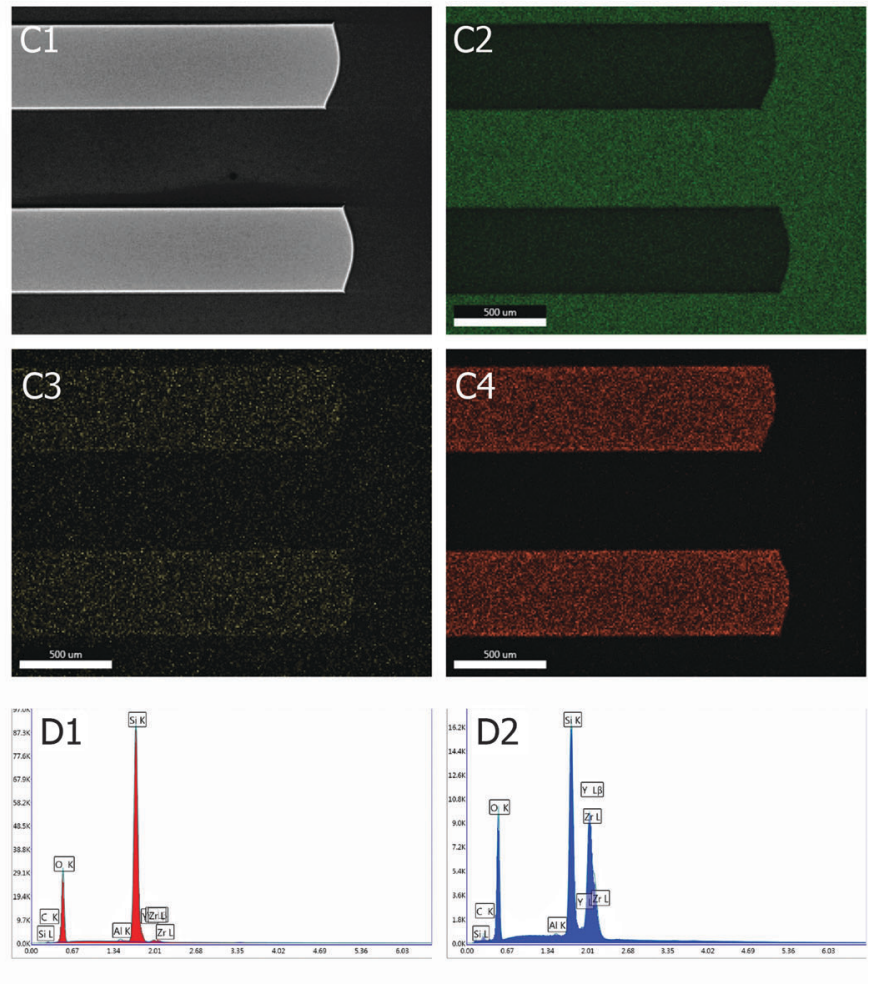

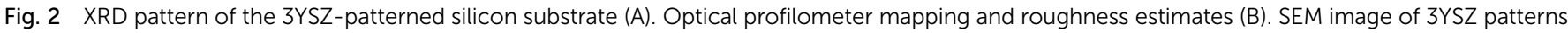

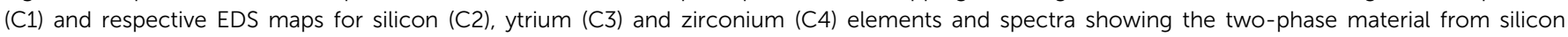
substrate (D1) and deposited 3YSZ (D2). 

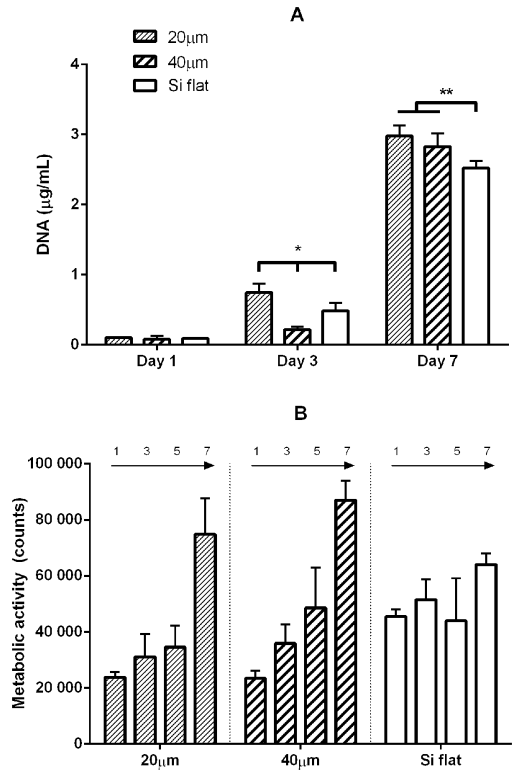

Fig. 3 DNA concentration (A) and metabolic activity (B) of MG-63 cells cultured on patterned 3YSZ substrates and silicon control during 7 days.

without compromising cell viability. Regarding differences between the two patterns, at 3 days, the $20 \mu \mathrm{m}$ pattern showed a somewhat higher DNA amount as compared to the $40 \mu \mathrm{m}$ pattern, while this difference became smaller after 7 days. No significant differences were observed in metabolic activity between the two patterns. Studies in which topographical patterning (i.e. creation of grooves in the surface) was used to control cell orientation, have shown that the effect on proliferation was dependent on both the size of the features and the chemistry of the substrate. ${ }^{48,49}$ In our study, differences, although present, were relatively small, not providing conclusive evidence for an effect of the size of the pattern at this stage.

Surface topographical features have been shown to affect osteoblast adhesion and matrix deposition, leading to improved osteointegration of polymeric implants ${ }^{46}$ and micropatterned ceramics. ${ }^{50}$ According to the importance given to microtopography cues in controlling the cell function, ${ }^{51,52}$ the cell adhesion and morphology were evaluated at an early stage of culture. The morphology of MG-63 cells following $24 \mathrm{~h}$ and $72 \mathrm{~h}$ of culture on the different 3YSZ-patterned surfaces was evaluated by fluorescent microscopy, focusing on the cell shape and focal adhesions (Fig. 4A-F). Orientation was measured after $24 \mathrm{~h}$ (Fig. 4G) and $72 \mathrm{~h}$ (Fig. $4 \mathrm{H}$ ). Cell orientation was measured in degrees between the cell major axis and the direction of the patterned lines, with $0^{\circ}$ indicating perfect alignment with the pattern, and $90^{\circ}$ indicating orientation perpendicular to the patterns. A preferential alignment of cells along the patterned lines was observed for all patterns and at both time points against what was observed for the flat control: close to $40 \%$ of cells on the $20 \mu \mathrm{m}$ pattern and $30 \%$ on the $40 \mu \mathrm{m}$ were oriented between $0^{\circ}$ and $15^{\circ}$, against $15 \%$ of cells on the flat control. These results are in accordance with the studies by others reporting on the effect of grooved substrates on cell orientation, at various scales and in different types of materials. ${ }^{45,52-54}$
Cells cultured on the flat silicon substrate presented a smaller area than those cultured on 3YSZ patterns (Fig. 4I). Although the cell area of cells cultured on 20 or $40 \mu \mathrm{m}$ 3YSZ patterns decreased in time, it still remained larger when compared to the flat control.

Regarding the cell form factor parameter, which measures the cell elongation (in which 1 corresponds to a circular, and $<1$ to an oblong shape), it was shown that after $24 \mathrm{~h}$, spread cells with an elongated morphology were found over the entire surface of the flat substrate. This elongated shape was more pronounced on the $20 \mu \mathrm{m}$ 3YSZ patterns, and even more on the $40 \mu \mathrm{m}$ patterns (Fig. 4J). After $72 \mathrm{~h}$, the form factor was comparable between the patterned substrates and the flat control. The expression of vinculin, a focal adhesion protein, was higher on the flat than on the patterned substrates (Fig. $4 \mathrm{~K}$ ) at $24 \mathrm{~h}$. The same trend was observed after $72 \mathrm{~h}$, with an increase in the expression of vinculin on the control substrate. The increase in the recruitment of adhesion proteins such as vinculin and talin, along with integrin binding has been shown to correlate with an increase in cell spreading. ${ }^{55}$ Taken together, these data showed that the strongest effect of the 3YSZ patterns was on the orientation of the cells, in particular when the narrower patterned lines are considered. The effect on the cell area and form factor, being stronger for $40 \mu \mathrm{m}$ than for $20 \mu \mathrm{m}$ patterns, was visible at $24 \mathrm{~h}$ and decreased after a long culture period, and this effect was also reflected in the vinculin expression.

\section{Calcium phosphate micropatterning}

In the second part of the study, the ceramic patterning technique was modified to allow patterning of a CaP ceramic, which is a widely used ceramic in bone regeneration for its resemblance to the mineral portion of the natural bone, as well as its bioactivity in terms of osteoconduction, bone bonding, and sometimes even osteoinduction. ${ }^{56,57}$

Pattern characterization. The crystalline phase of the substrate patterned with CaP by employing the modified MIMIC technique was identified by XRD (Fig. 5A). The XRD patterns of the as-prepared (AP) sample showed peaks characteristic of dicalcium phosphate anhydrous (DCPA), specifically at $2 \theta=13^{\circ}$ (001), 26.4 (002 and 200) and 30.3 (220) (PDF\# 04-012-8346); $;^{\circ}$ while the high-temperature (HT) sample, annealed at $950{ }^{\circ} \mathrm{C}$ for $3 \mathrm{~h}$, showed peaks characteristic of $\beta$-tricalcium phosphate ( $\beta$-TCP), at $13.6^{\circ}(103), 17^{\circ}(110), 25.8^{\circ}(1010), 27.8^{\circ}(214), 31.0^{\circ}$ (0210) and $34.3^{\circ}$ (220) (PDF\# 04-008-8714). ${ }^{59-61}$ The sharp peak at $2 \theta=33^{\circ}$ corresponds to silicon (100) and originates from the substrate. ${ }^{62}$

Both the AP and the HT CaP patterns consisted of elongated crystals with radially branching morphology, which at some sections did not fully occupy the volume defined by the mould after evaporation of the solvent (Fig. 5D1, D2). Both the crystalline surface features and the inhomogeneity of the pattern coverage were in obvious contrast to what was achieved with 3YSZ, by employing the same patterning technique. No apparent alterations in the crystal morphology were observed after heat-treatment of the AP ceramic. The DCPA phase obtained is in agreement with what is expected under the conditions 


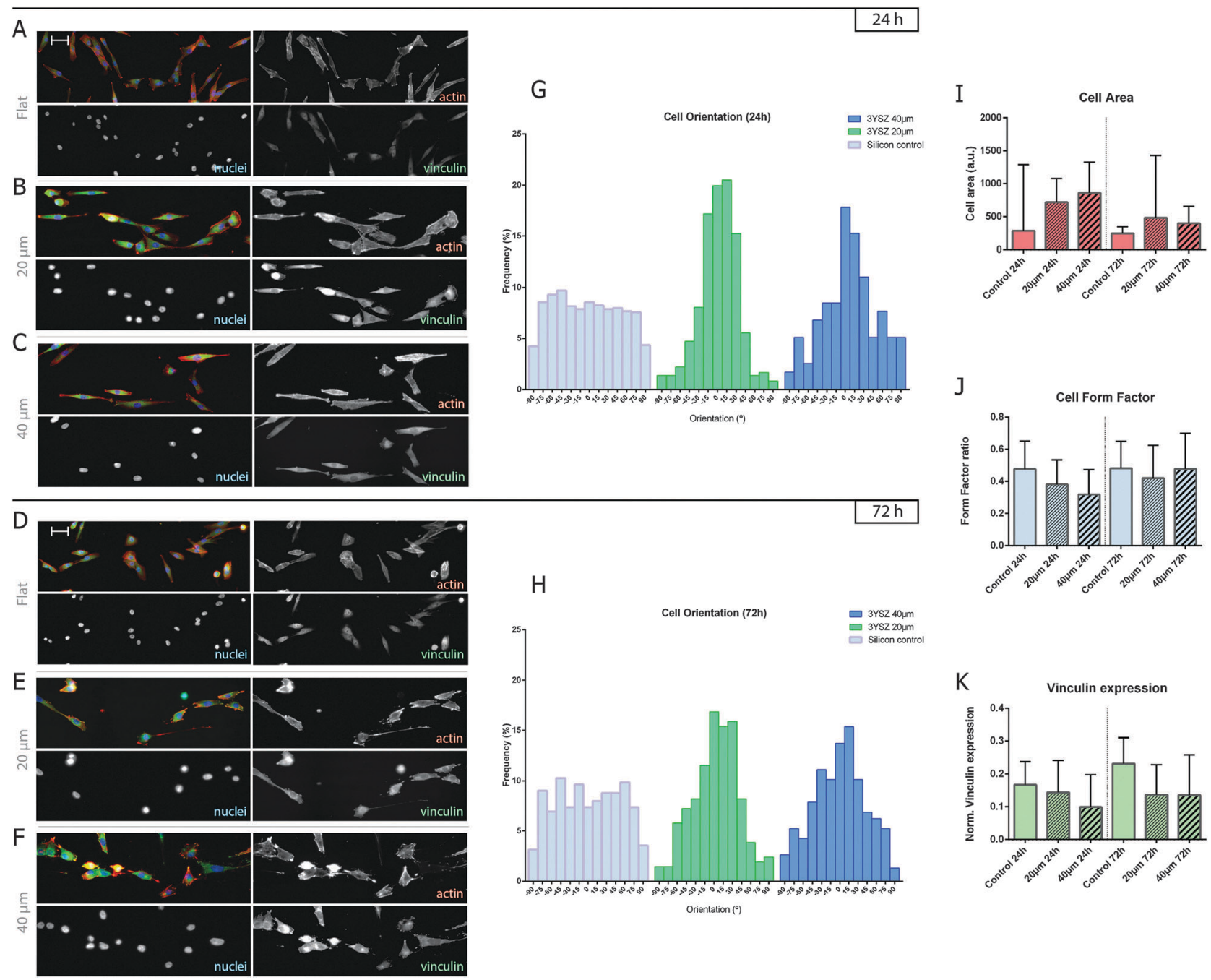

Fig. 4 Fluorescent labelling of F-actin (red), vinculin (green) and cell nuclei (blue) of MG63 cells cultured on flat and 3YSZ-patterned silicon substrates after $24 \mathrm{~h}$ ( $\mathrm{A}$ for flat, B for $20 \mu \mathrm{m}$, and $\mathrm{C}$ for $40 \mu \mathrm{m}$ ) and $72 \mathrm{~h}$ ( $\mathrm{D}$ for flat, $\mathrm{E}$ for $20 \mu \mathrm{m}$ and $\mathrm{F}$ for $40 \mu \mathrm{m}$ ) (scale bar $=100 \mu \mathrm{m}$ ), with respective frequency distribution for cell orientation ( $\mathrm{G}$ at $24 \mathrm{~h}$ and $\mathrm{H}$ at $72 \mathrm{~h}$ ). Shape descriptors of cells: area (I), form factor (J) and normalised vinculin expression (K).

during patterning, namely low $\mathrm{pH}$ of the solution, low water availability and the presence of alcohol groups. ${ }^{63,64}$ The conversion of DCPA to $\beta$-TCP upon heat treatment has been reported for annealing temperatures of about $900-1100{ }^{\circ} \mathrm{C} .{ }^{60,65,66}$

Roughness quantification $\left(R_{\mathrm{q}}\right)$ by optical profilometry yielded similar results for the AP and HT samples, with submicron features both in the longitudinal ( $893 \pm 462 \mathrm{~nm}$ for AP, $625 \pm$ $48 \mathrm{~nm}$ for HT) and in the crossing direction $(776 \pm 211 \mathrm{~nm}$ for $\mathrm{AP}, 775 \pm 157 \mathrm{~nm}$ for HT) (Fig. 5B, C).

In accordance with the qualitative observations based on SEM images, the roughness measurements confirmed a significantly rougher morphology of the CaP patterns as compared to 3YSZ patterns. This was mainly due to sharp edges of the CaP crystals, introducing height variations close to $1 \mu \mathrm{m}$. Furthermore, submicron- and nanosized topographical features were observed on the surfaces of individual crystals (Fig. 5D1, D2). These features are in the scale range of topographical cues previously described to affect the cell attachment, contact guidance and proliferation. ${ }^{46,67}$
EDS analysis of the CaP patterned substrates identified the Si substrate and the CaP phase, both in the AP and HT samples. Elemental mapping confirmed the deposition of a phase containing calcium and phosphorus, and showed a homogenous distribution of both elements geometrically confined to the microchannels where precipitation occurred (Fig. 5D1, D2). Differences in the distribution of calcium and phosphorus elements were observed between the AP and HT samples. While in the AP samples, the presence of phosphorus was clearly confined to the shape of the crystals, calcium did not have the same sharply defined distribution. After heat-treatment, the distribution of both elements was similar.

To determine which CaP phase is the most suitable for the cell culture experiments, i.e. allows a reliable analysis of the effect of patterns on the cell behaviour, the stability of the patterned CaP ceramics was assessed by ageing in the aqueous environment. SEM micrographs (Fig. 6) of CaP patterned samples before and after 3 days of ageing in cell culture medium showed significant alteration of AP pattern, while no such alterations were observed 
A
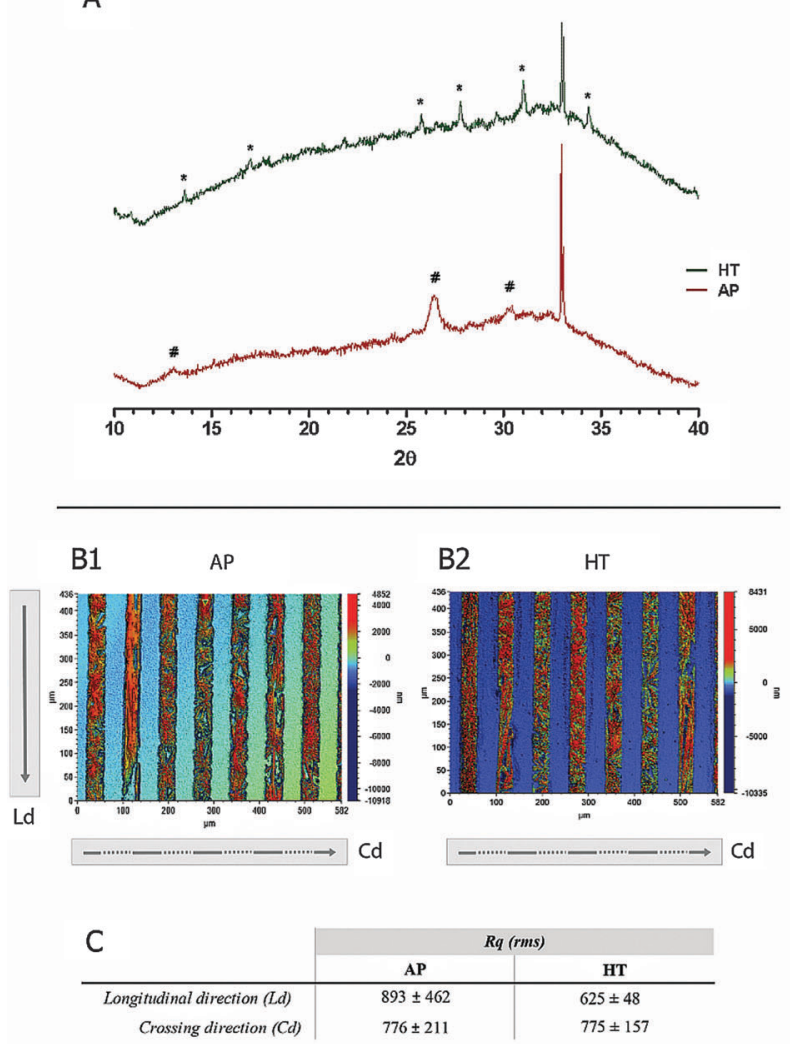

D1

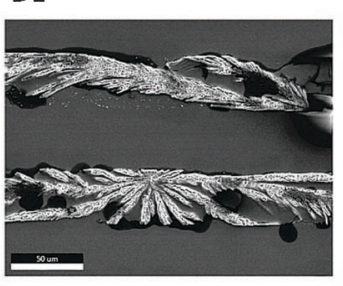

AP
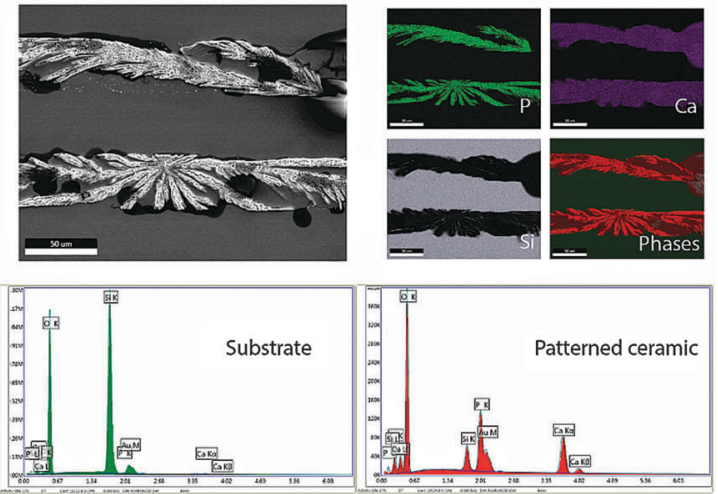

D2

HT
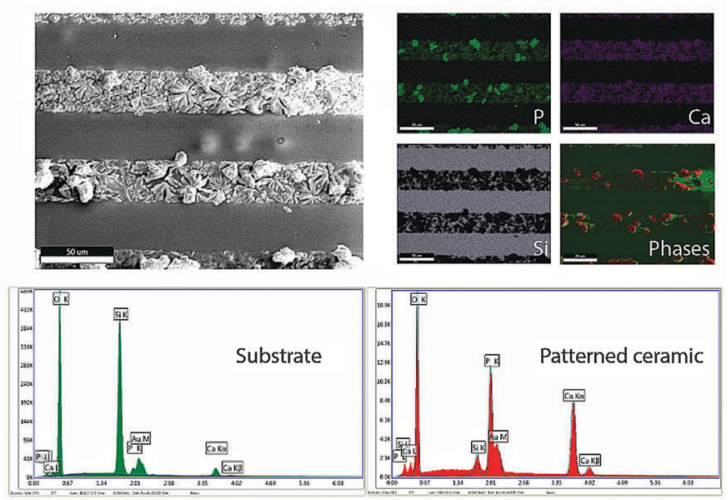

Fig. 5 XRD pattern (A) of as-prepared (AP - red) and high-temperature (HT - green) CaP patterns. Optical profilometer mapping of AP (B1) and HT (B2) patterns and respective roughness measurements (C). SEM image, respective EDS maps for phosphorous (P), calcium (Ca) and silicon (Si) and phase distribution (with spectra) of AP (D1) and HT (D2) patterns.

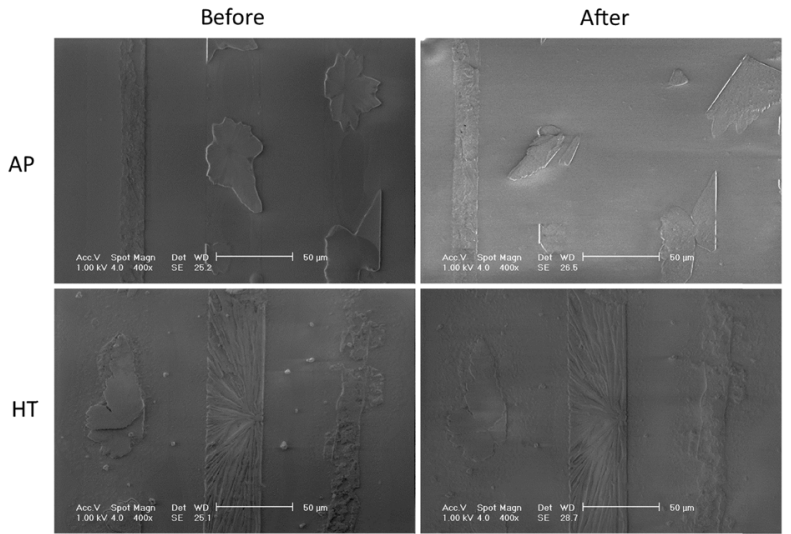

Fig. 6 SEM images of as-prepared (AP) and high-temperature (HT) CaP patterns, before and after ageing in cell culture medium for 3 days.

in the HT samples, which is to be expected based on the thermodynamic stability of the two CaP phases. ${ }^{68}$ Although we cannot exclude the possibility that cracking and crystal displacement may also have been caused by handling during sterilization and media change, instead of being a result of the dissolution process, the heat treatment clearly stabilized the ceramic material.
Cell proliferation, metabolic activity and morphology on CaP patterns. In line with the results obtained for the zirconia patterns, MG-63 cells proliferated between day 1 and day 7 when cultured on CaP patterns having a line width of 5,20 or $80 \mu \mathrm{m}$ (Fig. 7A). An increase was also observed on the unpatterned silicon substrate, where the DNA levels after 7 days were slightly lower than on 5 and $20 \mu \mathrm{m}$ CaP patterns. The smaller width patterns also showed a somewhat more pronounced cell proliferation as compared to the $80 \mu \mathrm{m}$ pattern. An increasing trend in metabolic activity of cells was also observed, without differences between different CaP patterns. The cells cultured on the flat silicon substrate showed a somewhat slower temporal increase in metabolic activity (Fig. 7B). The data on DNA amounts and metabolic activity on CaP patterns were in accordance with the data obtained on 3YSZ patterns, confirming cell viability and proliferation on all substrates.

The morphology of human osteosarcoma MG-63 cells following $24 \mathrm{~h}$ and $72 \mathrm{~h}$ of culture on the different $\mathrm{CaP}$ patterned surfaces was evaluated by fluorescent microscopy (Fig. 8A, B) and SEM (Fig. 9).

Regarding cell orientation, over $50 \%$ of the cells were aligned at an angle between $0^{\circ}$ and $15^{\circ}$ of the pattern direction, suggesting a strong orientation effect. Differences in orientation were found between patterns with different line widths. After $24 \mathrm{~h}$, differences were observed between the cell orientation distribution on the narrower patterns of $1-5,10$, and $20 \mu \mathrm{m}$ 

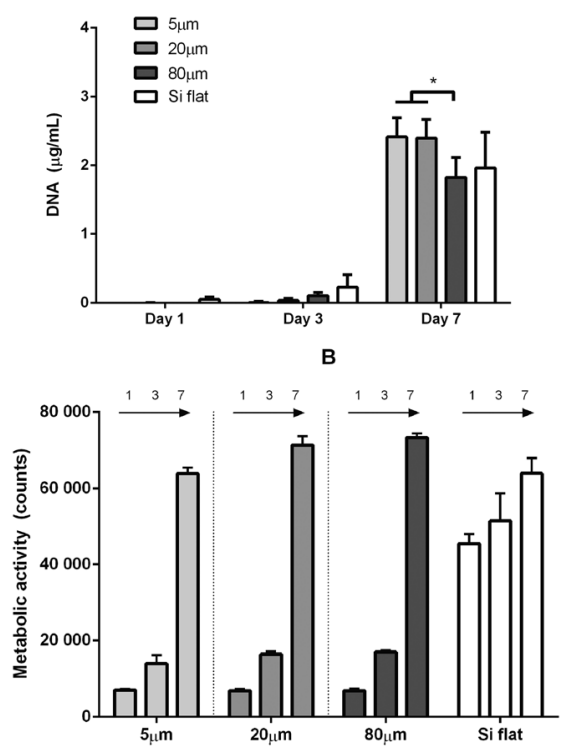

Fig. 7 DNA concentration (A) and total metabolic activity (B) of MG- 63 cells cultured on patterned CaP substrates and silicon control for 1, 3 and 7 days.

relative to the larger 40 and $80 \mu \mathrm{m}$ patterns (Fig. 8C). The narrow patterns showed a higher percentage of cells within $15^{\circ}$ of the direction of the lines, respectively $64.9,57.7$ and $81.5 \%$ on $1-5,10$, and $20 \mu \mathrm{m}$ line patterns. On 40 and $80 \mu \mathrm{m}$ patterns, these percentages were 53.6 and $51.9 \%$, respectively. At $72 \mathrm{~h}$ the percentage of cells within $15^{\circ}$ alignment increased on the 1-5 and $10 \mu \mathrm{m}$ lines to 70.3 and $78.3 \%$, respectively. There was a slight decrease to $75 \%$ for the $20 \mu \mathrm{m}$ lines, while for cells on the 40 and $80 \mu \mathrm{m}$ lines, the decrease was significant, to $50 \%$ and $32.1 \%$ respectively (Fig. 8D). These data show that the degree of cell orientation depends on the lateral dimensions of the pattern lines, with smaller features resulting in more oriented cells, an effect observed for osteoblast-like cells in a number of studies, as discussed by Holthaus et al. ${ }^{69}$ Furthermore, the extent of orientation in time was different, with cells on the narrow patterns becoming increasingly oriented in time, in contrast to the cells on wider patterns, where the level of orientation decreased between $24 \mathrm{~h}$ and $72 \mathrm{~h}$. An increase in the average orientation angle between 24 and $72 \mathrm{~h}$ (reflecting a decrease in alignment) was observed for SaOS-2 cultured on grooves ranging from 7.5 to $40 \mu \mathrm{m}$ width, although in this case the narrow patterns $(7.5$ and $15 \mu \mathrm{m})$ exhibited the same loss of alignment as the wider patterns $(25,30$, and $40 \mu \mathrm{m}){ }^{70}$

Quantification of cell morphology parameters showed that the cell area did not considerably change on different pattern widths. While on $1-5,40$ and $80 \mu \mathrm{m}$ patterns the cell area remained constant between $24 \mathrm{~h}$ and $72 \mathrm{~h}$, the cells cultured on $10 \mu \mathrm{m}$ or $20 \mu \mathrm{m}$ patterns increased in size over time (Fig. $8 \mathrm{E}$ ). A decrease in the form factor was observed for the 1-5, 10 and $20 \mu \mathrm{m}$ patterns between 24 and $72 \mathrm{~h}$, while it remained the same for the 40 and $80 \mu \mathrm{m}$ patterns (Fig. 8F), suggesting that together with the increased degree of orientation described above, cells became
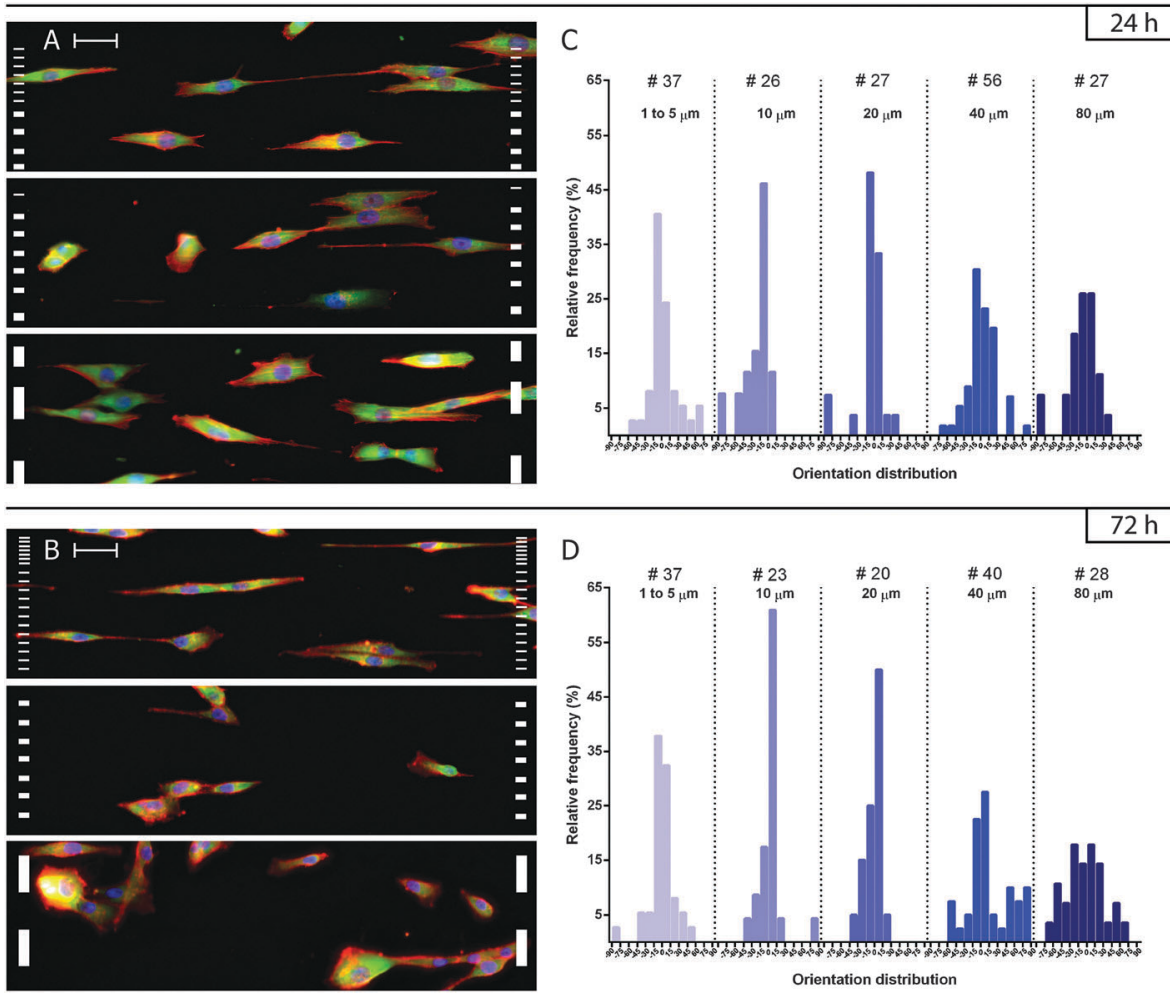
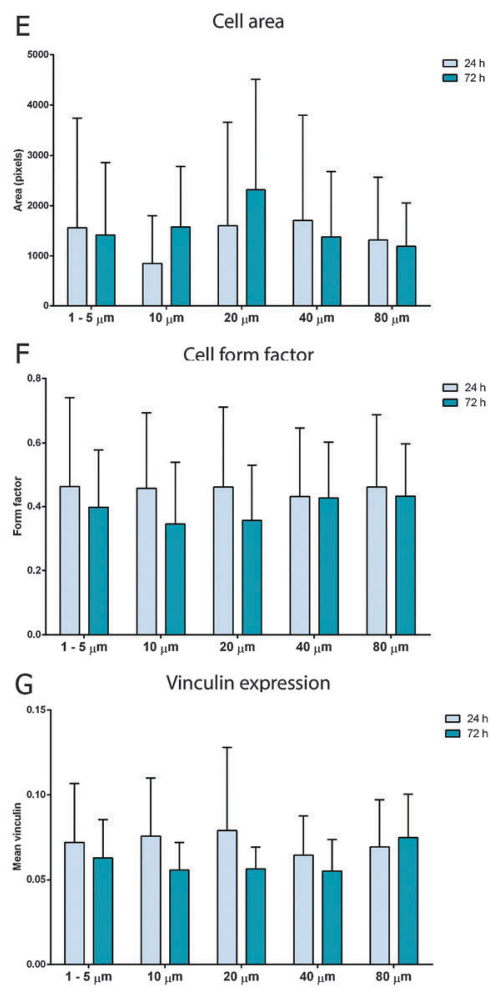

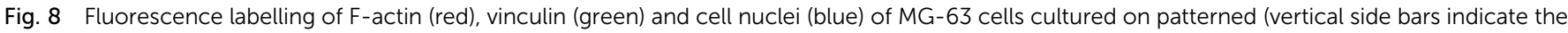

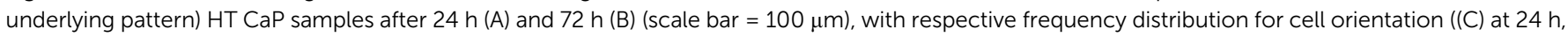
and (D) at 72 h) and cell shape descriptors: cell area (E), form factor (F) and mean vinculin intensity (G). 
$24 \mathrm{~h}$

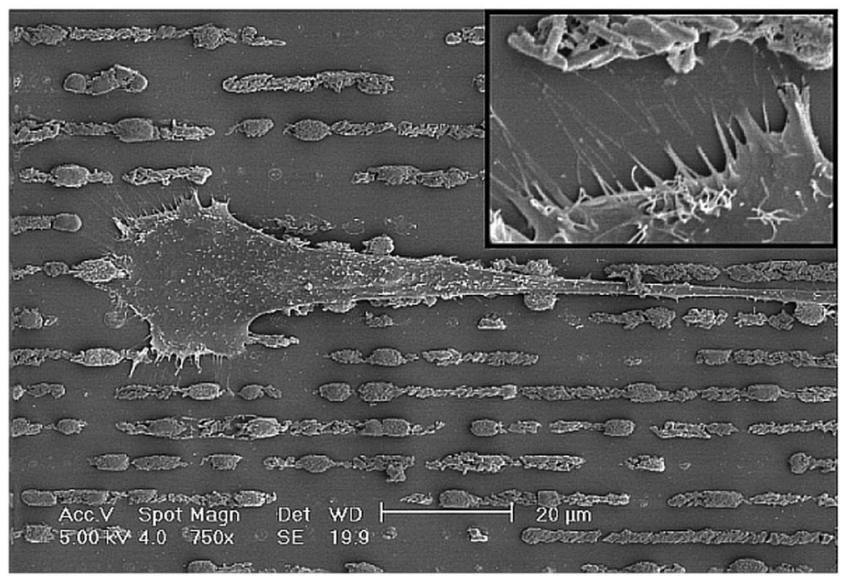

$72 \mathrm{~h}$

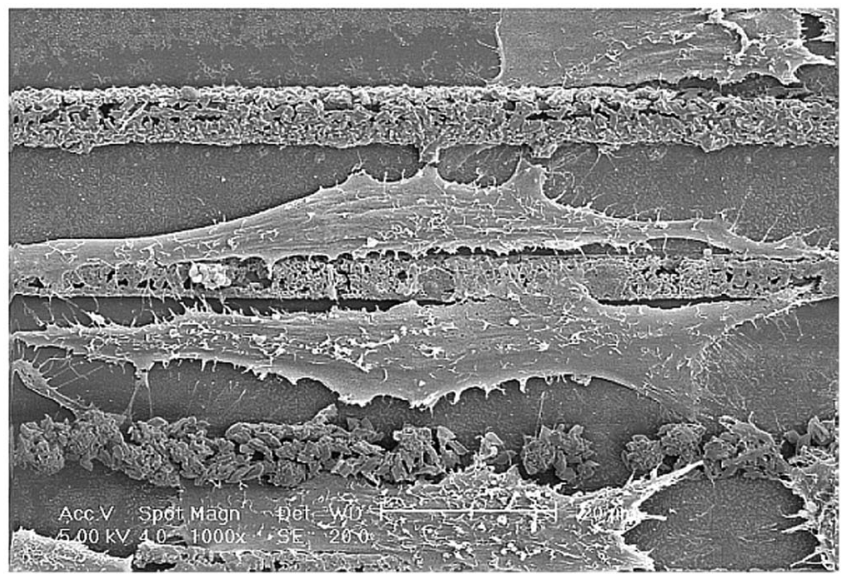

Fig. 9 SEM micrographs of MG-63 cells cultured on the HT CaP patterned substrates, after $24 \mathrm{~h}$ and $72 \mathrm{~h}$. The inset at $24 \mathrm{~h}$ shows magnification of cytoplasm protrusions from lamellipodia.

more elongated on the narrower patterns. Mean vinculin intensity was slightly lower on 1-5, 10, 20 and $40 \mu \mathrm{m}$ patterns after $72 \mathrm{~h}$, while for the $80 \mu \mathrm{m}$ pattern it remained comparable (Fig. 8G). This might suggest fewer or smaller focal adhesion complexes on patterned surfaces, as was shown before for rat calvarial osteoblast on polycarbonate grooves of 10 and $30 \mu \mathrm{m}$ in width. ${ }^{71}$

In summary, cells on narrow patterns (1-5, 10 and $20 \mu \mathrm{m})$ were more strongly affected by the substrate topography. They were seen to increase their alignment parallel to the underlying pattern, and to alter their shape into a more elongated morphology after $72 \mathrm{~h}$. In contrast, the cells on the wider patterns (40 and $80 \mu \mathrm{m}$ width) were less influenced by the surface topography, as they became more randomly oriented after $72 \mathrm{~h}$, and showed no appreciable changes in morphology.

The SEM micrographs (Fig. 9) upon cell culture indeed showed that the CaP patterning method needs further improvement, especially with regard to homogeneity of the deposited ceramic phase. MG-63 cells showed cell filopodia interacting mainly with the ceramic edges presented by the CaP patterns, but also with the silicon background. Adhesion is a critical step in the interaction of cells with a biomaterial, as it allows proliferation and initial gene regulation by means of mechanotransduction. ${ }^{72,73}$ Bioceramics, against other synthetic biomaterials, provide complex cues derived from crystalline microstructure and local ion concentration, directing tissue towards osteogenic commitment. ${ }^{74,75}$ These findings highlight the relevance of providing a new generation of instructive bioceramics with controlled surface chemistry and topography, e.g. by patterning techniques.

\section{Conclusion}

MIMIC was successfully employed as a method for patterning 3YSZ and $\mathrm{CaP}$ ceramics on a silicon substrate. Both types of patterns were able to sustain osteoblast-like MG-63 cell adhesion and proliferation. Dimensions of an array of parallel ceramic lines (both 3YSZ and $\mathrm{CaP}$ ) were found to have different effects on cell alignment and morphology. Cells were more aligned and elongated on line patterns with a width of up to $20 \mu \mathrm{m}$ than on wider, 40 or $80 \mu \mathrm{m}$ wide patterns. Furthermore, the ability to retain the elongated shape over a longer period of time was more pronounced on the narrower patterns. These findings are in agreement with what has been described as contact guidance by grooved substrates, ${ }^{69}$ and serve as an example of the correlations that can be established between biomaterial's properties and instructed cell behaviour. It should however be emphasized that the patterns used in our study were not grooves, but ceramic deposits on the flat substrate.

The ability to pattern a material of choice against a nonadherent background is the underlying technical aspect of platforms used to study cell-material interactions ${ }^{5,38}$ and to spatially control cell behaviour on the surface, and its applicability to bioceramic materials remains a challenge to overcome. Although we have demonstrated that MIMIC is a suitable technique to pattern ceramics, from the bioinert 3YSZ to the bioactive $\mathrm{CaP}$ ceramics, the process requires further refinement. This is particularly the case for the CaP patterning where the homogeneity and coherence of the deposited phase needs to be optimised and the technique needs to be extended to other chemical phases and to different substrates.

\section{Acknowledgements}

DB gratefully acknowledges the financial support of the NIRM (Netherlands Institute of Regenerative Medicine). This research has been in part made possible with the support of the Dutch Province of Limburg. The authors would like to thank Gerard Cadafalch for his help with XRD data analysis.

\section{References}

1 D. F. Williams, Biomaterials, 2008, 29, 2941-2953.

2 B. D. Ratner, J. Cardiovasc. Transl. Res., 2011, 4, 523-527.

3 B. N. Brown and S. F. Badylak, Acta Biomater., 2013, 9, 4948-4955. 
4 D. Falconnet, G. Csucs, H. M. Grandin and M. Textor, Biomaterials, 2006, 27, 3044-3063.

5 X. Yao, R. Peng and J. Ding, Adv. Mater., 2013, 25, 5257-5286.

6 C. Yan, J. Sun and J. Ding, Biomaterials, 2011, 32, 3931-3938.

7 R. Peng, X. Yao and J. Ding, Biomaterials, 2011, 32, 8048-8057.

8 K. A. Kilian, B. Bugarija, B. T. Lahn and M. Mrksich, Proc. Natl. Acad. Sci. U. S. A., 2010, 107, 4872-4877.

9 B. Vahidi, J. W. Park, H. J. Kim and N. L. Jeon, J. Neurosci. Methods, 2008, 170, 188-196.

10 J. Chevalier and L. Gremillard, in Comprehensive Biomaterials, ed. P. Ducheyne, Elsevier, Oxford, 2011, pp. 95-108.

11 I. Denry and J. R. Kelly, Dent. Mater., 2008, 24, 299-307.

12 G. Daculsi, B. Fellah and T. Miramond, in Advances in Calcium Phosphate Biomaterials, ed. B. Ben-Nissan, Springer, Berlin Heidelberg, 2014, vol. 2, pp. 71-96.

13 S. V. Dorozhkin, in Advances in Calcium Phosphate Biomaterials $S E$ - 15, ed. B. Ben-Nissan, Springer, Berlin Heidelberg, 2014, vol. 2, pp. 435-483.

14 M. Bohner, L. Galea and N. Doebelin, J. Eur. Ceram. Soc., 2012, 32, 2663-2671.

15 M. G. Holthaus, L. Treccani and K. Rezwan, J. Eur. Ceram. Soc., 2011, 31, 2809-2817.

16 M. A. Anger, P. L. Schilardi, I. Caretti, O. Sánchez, G. Benítez, J. M. Albella, R. Gago, M. Fonticelli, L. Vázquez, R. C. Salvarezza and O. Azzaroni, Small, 2005, 1, 300-309.

17 M. Alexe, C. Harnagea and D. Hesse, J. Electroceram., 2004, 12, 69-88.

18 C. S. Chen, M. Mrksich, S. Huang, G. M. Whitesides and D. E. Ingber, Science, 1997, 276, 1425-1428.

19 E. Kim, Y. Xia and G. M. Whitesides, J. Am. Chem. Soc., 1996, 118, 5722-5731.

20 X. M. Zhao, Y. N. Xia and G. M. Whitesides, Adv. Mater., 1996, 8, 837-840.

21 S. Y. Chou, P. R. Krauss and P. J. Renstrom, Science, 1996, 272, 85-87.

22 A. Kumar and G. M. Whitesides, Appl. Phys. Lett., 1993, 63, 2002-2004.

23 W. S. Beh, Y. Xia and D. Qin, J. Mater. Res., 1999, 14, 3995-4003.

24 O. F. Göbel, D. H. A. Blank and J. E. ten Elshof, ACS Appl. Mater. Interfaces, 2010, 2, 536-543.

25 S. U. Khan and J. E. ten Elshof, Sci. Technol. Adv. Mater., 2012, 13, 025002.

26 S. Veldhuis, A. George, M. Nijland and J. E. ten Elshof, Langmuir, 2012, 28, 15111-15117.

27 B. S. Seraji, Y. Wu, N. E. Jewell-larson, M. J. Forbess, S. J. Limmer and T. P. Chou, Adv. Mater., 2000, 12, 1421-1424.

28 Z. Y. Cheng, Z. Wang, R. B. Xing, Y. C. Han and J. Lin, Chem. Phys. Lett., 2003, 376, 481-486.

29 X. M. Han, J. Lin, J. Fu, R. B. Xing, M. Yu, Y. H. Zhou and M. L. Pang, Solid State Sci., 2004, 6, 349-355.

30 X. M. Han, J. Lin, R. B. Xing, J. Fu and S. B. Wang, Mater. Lett., 2003, 57, 1355-1360.

31 X. M. Han, J. Lin, R. B. Xing, J. Fu, S. B. Wang and Y. C. Han, J. Phys.: Condens. Matter, 2003, 15, 2115-2126.
32 M. L. Pang, J. Lin, J. Fu, R. B. Xing, C. X. Luo and Y. C. Han, Opt. Mater., 2003, 23, 547-558.

33 M. Yu, J. Lin, Z. Wang, J. Fu, S. Wang, H. J. Zhang and Y. C. Han, Chem. Mater., 2002, 14, 2224-2231.

34 K. H. Park, I. K. Sung and D. P. Kim, J. Mater. Chem., 2004, 14, 3436-3439.

35 D.-H. Lee, K. H. Park, L.-Y. Hong and D. P. Kim, Sens. Actuators, A, 2007, 135, 895-901.

36 A. Pelaez-Vargas, D. Gallego-Perez, A. Carvalho, M. H. Fernandes, D. J. Hansford and F. J. Monteiro, J. Biomed. Mater. Res., Part B, 2013, 101, 762-769.

37 M. S. Laranjeira, Â. Carvalho, A. Pelaez-Vargas, D. Hansford, M. P. Ferraz, S. Coimbra, E. Costa, A. Santos-Silva, M. H. Fernandes and F. J. Monteiro, Sci. Technol. Adv. Mater., 2014, 15, 025001.

38 Y. He, X. Wang, L. Chen and J. Ding, J. Mater. Chem. B, 2014, 2, 2220.

39 P. Palmero, M. Fornabaio, L. Montanaro and H. Reveron, Biomaterials, 2015, 50, 38-46.

40 M.-H. Lin, C.-F. Chen, H.-W. Shiu, C.-H. Chen and S. Gwo, J. Am. Chem. Soc., 2009, 131, 10984-10991.

41 D. G. Lamas and N. E. Walsoe de Reca, J. Mater. Sci., 2000, 35, 5563-5567.

42 C. R. Martin and I. A. Aksay, J. Phys. Chem. B, 2003, 107, 4261-4268.

43 J. Ballester-Beltrán, M. Biggs, M. J. Dalby, M. SalmeronSanchez and A. Leal-Egaña, Front. Mater., 2015, 2, 39, DOI: 10.3389/fmats.2015.00039.

44 M. J. P. Biggs and M. J. Dalby, Proc. Inst. Mech. Eng., Part H, 2010, 224, 1441-1453.

45 S. T. Wong, S.-K. Teo, S. Park, K.-H. Chiam and E. K. F. Yim, Biomech. Model. Mechanobiol., 2014, 13, 27-39.

46 A. Wilkinson, R. N. Hewitt, L. E. McNamara, D. McCloy, R. M. D. Meek and M. J. Dalby, Acta Biomater., 2011, 7, 2919-2925.

47 N. W. Karuri, S. Liliensiek, A. I. Teixeira, G. Abrams, S. Campbell, P. F. Nealey and C. J. Murphy, J. Cell Sci., 2004, 117, 3153-3164.

48 K. Matsuzaka, F. Walboomers, A. Ruijter and J. A. Jansen, Clin. Oral Implants Res., 2000, 11, 325-333.

49 L. Jiang, X. Lu, Y. Leng, S. Qu, B. Feng, J. Weng and F. Watari, Mater. Sci. Eng., C, 2012, 32, 742-748.

50 M. Halai, A. Ker, R. D. Meek, D. Nadeem, T. Sjostrom, B. Su, L. E. McNamara, M. J. Dalby and P. S. Young, J. Tissue Eng., 2014, 5, 2041731414552114.

51 L. D. Markert, J. Lovmand, M. Foss, R. H. Lauridsen, M. Lovmand, E.-M. Fuchtbauer, A. Fuchtbauer, K. Wertz, F. Besenbacher, F. S. Pedersen and M. Duch, Stem Cells Dev., 2009, 18, 1331-1342.

52 C. J. Bettinger, R. Langer and J. T. Borenstein, Angew. Chem., Int. Ed., 2009, 48, 5406-5415.

53 Y. Yang, K. Kulangara, J. Sia, L. Wang and K. W. Leong, Lab Chip, 2011, 11, 1638-1646.

54 E. Rebollar, I. Frischauf, M. Olbrich, T. Peterbauer, S. Hering, J. Preiner, P. Hinterdorfer, C. Romanin and J. Heitz, Biomaterials, 2008, 29, 1796-1806. 
55 N. D. Gallant, K. E. Michael and A. J. Garcia, Mol. Biol. Cell, 2005, 16, 4329-4340.

56 A. M. C. Barradas, H. Yuan, C. A. Van Blitterswijk and P. Habibovic, Eur. Cells Mater., 2011, 21, 407-429.

57 P. Habibovic, D. C. Bassett, C. J. Doillon, C. Gerard, M. D. McKee and J. E. Barralet, Adv. Mater., 2010, 22, 1858-1862.

58 M. Catti, G. Ferraris and S. A. Mason, Acta Crystallogr., Sect. B: Struct. Crystallogr. Cryst. Chem., 1980, 36, 254-259.

59 Structure and Chemistry of the Apatites and Other Calcium Orthophosphates, ed. J. C. Elliott, Elsevier, 1994, vol. 18, pp. 305-310.

60 H. Eshtiagh-Hosseini, M. R. Houssaindokht, M. Chahkandhi and A. Youssefi, J. Non-Cryst. Solids, 2008, 354, 3854-3857.

61 B. Dickens, L. W. Schroeder and W. E. Brown, J. Solid State Chem., 1974, 10, 232-248.

62 M. A. Niedermeier, D. Magerl, Q. Zhong, A. Nathan, V. Körstgens, J. Perlich, S. V Roth and P. Müller-Buschbaum, Nanotechnology, 2012, 23, 145602.

63 A. C. Tas, J. Am. Ceram. Soc., 2009, 92, 2907-2912.

64 F. Tamimi, Z. Sheikh and J. Barralet, Acta Biomater., 2012, 8, 474-487.

65 J. Duncan, J. F. Macdonald, J. V Hanna, Y. Shirosaki, S. Hayakawa, A. Osaka, J. M. S. Skakle and I. R. Gibson, Mater. Sci. Eng., C, 2014, 34, 123-129.
66 G. Berger, R. Gildenhaar, U. Ploska, F. Driessens and J. a. Planell, Mater. Res., 1997, 6, 7-9.

67 E. Kingham, K. White, N. Gadegaard, M. J. Dalby and R. O. C. Oreffo, Small, 2013, 9, 2140-2151.

68 S. V. Dorozhkin, Biomaterials, 2010, 31, 1465-1485.

69 M. G. Holthaus, J. Stolle, L. Treccani and K. Rezwan, Acta Biomater., 2012, 8, 394-403.

70 X. Lu and Y. Leng, J. Biomed. Mater. Res., Part A, 2003, 66, 677-687.

71 G. Kirmizidis and M. A. Birch, Tissue Eng., Part A, 2009, 15, 1427-1436.

72 P. Tsimbouri, N. Gadegaard, K. V. Burgess, K. White, P. Reynolds, P. Herzyk, R. Oreffo and M. J. Dalby, J. Cell. Biochem., 2014, 115, 380-390.

73 J. Yang, L. E. McNamara, N. Gadegaard, E. V Alakpa, K. V. Burgess, R. M. D. Meek and M. J. Dalby, ACS Nano, 2014, 8, 9941-9953.

74 A. M. C. Barradas, H. A. M. Fernandes, N. Groen, Y. C. Chai, J. Schrooten, J. Van de Peppel, J. P. T. M. Van Leeuwen, C. a. Van Blitterswijk and J. De Boer, Biomaterials, 2012, 33, 3205-3215.

75 J. Zhang, X. Luo, D. Barbieri, A. M. C. Barradas, J. D. De Bruijn, C. a. Van Blitterswijk and H. Yuan, Acta Biomater., 2014, 10, 3254-3263. 